\title{
Trafik Güvenliği Açısından Genç Sürücü Parametrelerinin Analizi
}

\author{
${ }^{* 1}$ Hakan Aslan, ${ }^{2}$ Gökçe Gözükızıl ve ${ }^{3}$ Zeliha Çağla Kuyumcu \\ ${ }^{1,3}$ Sakarya Üniversitesi, Mühendislik Fakültesi, İnşaat Mühendisliği Bölümü, Sakarya, Türkiye \\ ${ }^{2}$ Türkiye Kömür İşletmeleri Genel Müdürlüğü, Ankara, Türkiye
}

$\ddot{O} z$

Genç sürücülerin, gerek sosyal gerekse de ekonomik hayata etkileri yadsınamaz olan trafik kazalarına karışma sebepleri ve bu kazaların arkasında bulunan ana faktörlerin belirlenmesi son derece önemlidir. Bu çalışmada 18-25 yaş aralığındaki genç sürücülerin karşılaştıkları kazalar ulusal ölçekte analiz edilmiş ve uluslararası ortak parametreler üzerinden değerlendirilmiştir. Mevcut verilerin geniş kapsamlı içeriğini; anlamlı, kullanışlı ve daha önceden bilinmeyen faydalı bilgi haline getirmek için Veri Madenciliği Yöntemleri kullanılarak detaylı bir analiz yapılmış olup, bu anlamda WEKA yazılımı kullanılmıştır. Birliktelik Kuralları ve diğer ilgili parametreler ışı̆̆ında, kazaların meydana gelmesinde rol oynayan karşılıklı faktörsel etkilerin değerlendirilmesi ile, kaza sayılarının azaltılmasına dönük sosyal, stratejik, işletimsel ve eğitim içerikli önerilerde bulunulmuştur.

Anahtar Kelimeler: Yol Güvenliği,Genç Sürücü Davranışları, Trafik Kaza Analizleri, Veri Madenciliği

\begin{abstract}
The reasons for young drivers to be involved in traffic accidents and identification of the main factors behind these accidents are a problem on a global scale since the effects of these accidents on both the social and economic life are undeniable. In this paper, the accidents caused by young drivers between the ages of 18 and 25 years old were analysed on a national scale and evaluated through international common parameters. Due to the nature of the extensive content of available data; a detailed analysis has been carried out by using Data Mining Methods in order to obtain useful, meaningful and previously unknown information by employing WEKA software. In the light of Association Rules and other relevant parameters, social, strategical, operational and educational recommendations were made to decrease the nationwide number of accidents.
\end{abstract}

Key Words:: Road Safety, Behaviour of Young Drivers, Traffic Accident Analysis, Data Mining

\section{Giriş}

Genç sürücü sayısındaki hızlı artış beraberinde, bu sürücülerin yaşanan trafik kazalarındaki etkileme ve etkilenme sayısındaki artışı da ortaya çıkarmaktadır. Bu çerçevede, ülkemizdeki durumun tespit edilebilmesi için, yaşanan trafik kazalarındaki veriler titizlikle analiz edilmeli ve genç sürücülerin bu kazalardaki rollerine dikkat edilmelidir. Trafik kazalarının oluşumuna birçok parametre aynı anda etki edebilmektedir. Her bir parametre ayrı ayrı ve birlikte değerlendirilerek, kazalara olan etkileri ve bu etkilerin kapsamları ortaya konulmalıdır. Bu analizler ve elde edilecek sonuçlar sayesinde, genç sürücülerin ülkemizde yaşanan trafik kazalarına karışım oranları azaltılabilecektir.

Bu çalışmada, ülkemizde yaşanan trafik kazalarına ait veriler, küresel ölçekte hazırlanan yol güvenliği çalışmalarındaki ortak parametrelere göre, veri madenciliği de kullanılarak analiz edilip

*Corresponding author: Hakan Aslan, Adres: Mühendislik Fakültesi, İnşaat Mühendisliği Bölümü, Sakarya Universitesi, 54187, Sakarya TURKIYE. E-mail address: haslan@ @akarya.edu.tr , Phone: +90 2642955752 
değerlendirilmiştir. Ortaya çıkan sonuçlar bir veri madenciliği aracı olan WEKA yazılımında test edilerek anlamlı ilişkiler elde edilmiş, analitik sonuçlar ortaya konulmuştur.

\section{Literatür}

2010 yılında Bloomberg Philanthropies tarafindan fonlanan ve Dünya Sağlık Örgütü (WHO) koordinasyonunda sürdürülen bir program başlatılmıştır. RS10 adı verilen bu program; trafik kazalarının yoğun olarak yaşandığı, dünya genelinde gerçekleşen toplam kazaların neredeyse yarısının meydana geldiği on ülkeyi kapsamaktadır. Programın hedefi, 2020 yılında trafik kazası kaynaklı 5 milyon insanın ölümünün önüne geçmektir. Bu hedef doğrultusunda, Brezilya, Kamboçya, Çin, Mısır, Hindistan, Kenya, Rusya, Meksika, Vietnam ile birlikte Türkiye de yol güvenliğini arttırıcı çalışmalar için çaba göstermektedir [1].

2012 yılında, Türkiye'de yol güvenliği politikaları ve stratejilerini önceliklendiren Karayolu Güvenliği Yüksek Kurulu oluşturulmuştur. "Yol Güvenliğinde 10 yıllık Eylem Planı" adı altında, trafik kazası kaynaklı ölümlerin 2020 yılına kadar \% 50 oranında azaltılmasını hedefleyen stratejiler belirlenmiştir. Takip eden süreçte, 2013 yılının Nisan ayında Yol Güvenliği Platformu aktif hale getirilmiştir. Bu platform, yol güvenliği planını uygulamaya geçirerek kullanıcı alışkanlıklarının değiştirilmesi (yüksek hızın önlenmesi ve emniyet kemeri kullanımı vb) üzerine yoğunlaşmıştır. 2013 yılı Aralık ayında da; Dünya sağlık Örgütü (WHO), Küresel Yol Güvenliği Ortaklığı, Dünya Bankası, John Hopkins Üniversitesi, Uluslararası Güvenli Yol Seyahat Birliği gibi RS10 projesinin uluslararası ortaklarından biri olan EMBARQ Türkiye, Yol Güvenliği Laboratuvarı Projesi'ni başlatmıştır [1]. Yol Güvenliği Laboratuvarı, bir takım kriterler 1şı̆̆ında seçilmiş Türkiye'nin 5 şehrinin, yol güvenliği açısından en problemli 25 noktasında incelemelerin yapıldığı, yerel yönetimlere teknik destek sağlamak ve farkındalık yaratmak amacıyla hayata geçirilmiş bir projedir.

Sosyolojik anlamda "yaş" toplumsal yapı içerisinde önemli bir değişkendir ve gündelik yaşamın birçok alanının şekillenmesinde etkili olmaktadır. Gençlik dönemi UNESCO tarafından 15-25 yaş aralığında belirlenirken, Birleşmiş Milletler Örgütü (BM) 12-24 yaş aralığını öngörmüştür. Türkiye ise BM'nin belirlediği 12-24 yaş arasını gençlik dönemi olarak benimsemiştir. Gençlik dönemi böylece ergenlik yaşına girmeyle başlamakta ve 18 yaşından sonra da göreli olarak yetişkinlik dönemine adım atmış olmakla sonlanmaktadır. Gençlik bir alt kültür olarak, kendine özgü yaşama tarzı, düşünme yapısı, dili kullanma ve iletişim kurma biçimi olan bir dönemdir. Söz konusu fizyolojik değişiklikler ile buna bağlı olarak gelişen toplumsal değerlendirmeler gencin asi davranışlar, ani değişik hareketler ve kararsızlıklar göstermesine yol açmaktadır. Geçiş döneminin özelliği gereği gençlik; biyolojik, psikolojik ve toplumsal gelişim bakımından bireyin en zor ve en bunalımlı dönemidir. Kazanılan kimlik ve kişilik gelişimi ile birlikte toplumsal, ekonomik, siyasal ve kültürel birçok dinamiğin etkisi altında çok boyutlu bir gençlik sorunu ile karşılaşılmaktadır. Bu sorunların en aza indirilmesi konusunda araştırmaların yapılması, etkin ve uygun toplumsal politikaların uygulanması ve gençlere yönelik eğitim ve kendini geliştirme mekanizmalarının oluşturulması gerekmektedir.

Trafik kazalarının oluşumunda sürücünün yaşı önemli faktörlerden biridir. Tüm dünyada bu konuda yapılan birçok araştırma vardır ve araştırmaların çoğuna göre de kaza sıklığı ile sürücü yaşı 
arasında ilişkiler söz konusudur. Gençlerin daha fazla kazaya karışmaları ile ilgili bir çalışmada, yolları kullanan genç erkeklerin kazalara göreceli olarak daha fazla karışması, bütün dünya trafiğinde yaygın olarak gözlenen en önemli olgulardan biri olarak değerlendirilmektedir. Kaza analizlerinde nüfus başına ölüm, birim mesafe başına şiddetli kaza sayısı ve yayaların ölümü ile sonuçlanan kazaların, 10'lu yaşların sonları ile 20'li yaşların başlarında yüksek oranlar da ortaya çıktığ1 görülmüştür [2]. Kişiler yaşlandıkça karıştıkları kazalar da azalmaktadır. Bunun bir nedeni de yaşla birlikte tecrübenin artması ve araç kullanımının azalmasıdır.

Sürücü davranışları, kişilik özellikleri ve psikolojik belirtilerin trafik kazalarındaki rolünü araştıran Sümer, iki veya daha fazla kaza yapan sürücülerin hiç kaza yapmayan sürücülere göre daha fazla trafik hatası ve ihlali yaptığını, ayrıca güvenli sürüş becerilerinin düşük, heyecan arama ve saldırganlık eğilimlerinin yüksek olduğunu tespit etmiş̧tir [3].

Amado, kişilerin algı süreçlerinin davranışları etkilemedeki rolünün önemli etkisine vurgu yapmış, sürücülerin kendi hızlarını algılamasının seçeceği sürüş hızını belirleyeceğini, ayrıca mesafe ve temas algısının da hareket halinde olan araç sürücüsünün trafikte vereceği kararları etkileyeceğini belirtmiştir. Aynı çalışmada sürücü davranışının trafik psikolojisinde birçok çalışma ve değerlendirmenin konusu olduğu, birçoğunun dikkat, alg1 ve muhakeme gibi sürücülerin bilişsel süreçleri ile ilgili olduğu belirtilmiş ve bu bilişsel süreçlerin, sürücülerin sürücülük performanslarını yakından etkilediği öne sürülmüştür [4].

Özellikle yaş hususu ile ilgili olarak, sürücülerin araç kullanımındaki tecrübesi, yaşlarının vermiş olduğu heyecan ve aşırı güven faktörünün kişisel hatalardan kaynaklanan kazalarda önemli bir etken olduğu üzerinde durulmuştur [5]. Bir diğer çalışmada, günlük araç kullanım süresi, karış1lan en son trafik kazası tarihi, kazadan sonra sürüş biçiminde meydana gelen değiş̧iklikler ve sürücülerin yapmış olduğu aktivitelerden zevk alması gibi faktörlerin, sürücülerin trafik kazası yapıp yapmamalarında belirleyici olduğu sonucuna ulaşılmıştır [6].

Genç sürücülerle ilgili olarak yapılan araştırmalar, bu sürücülerin yaşam biçimi, sürücülük deneyimsizliği, beceri eksikliği, aşırı güvene bağlı risk alma, alkollü araç kullanma gibi davranışlarla beraber yüksek kaza riski taşıyan grup olduklarını ortaya koymaktadır [7].

Trafik kazaları dünyada tüm ölüm nedenleri arasında 8'inci sırada olup, ölenlerin büyük çoğunluğunu 15-29 yaş arası gençler oluşturmaktadır. Acil önlem alınmazsa 2030'da trafik kazalarına bağlı ölümlerin, ölüm nedenleri arasında 5'inci sıraya yükselmesi öngörülmektedir. Bazı ülkeler aldıkları önlemlerle trafik kazalarında yaralanan vatandaşlarının sayısını azaltmayı başarmaktadır. Afrika, her 100 bin kişiden 24.1'lik ölüm oranı ile trafik kazalarına bağlı ölümlerin en yüksek yaşandığı bölgedir. Türkiye'nin de içinde bulunduğu Doğu Akdeniz 21.3 ile ikinci sırada yer alırken Avrupa en düşük oranın, 10.3, olduğu yerdir. İstatistiklerin gösterdiği en ilginç sonuçlardan biri ise kazalarda ölenlerin yarısını yayalar ( $\%$ 22), bisiklet (\% 5) ve motosiklet sürücülerinin (\% 23) oluşturmasıdır [8]

Arabalarda ön koltuklarda emniyet kemerinin bağlı olması ölümcül yaralanmaları \% 50 engellerken, arka koltuklarda emniyet kemerinin bağlı olması \% 75'e kadar ölümcül yaralanmaları engellemektedir [8] 
Trafik kazalarının ölümle sonuçlanmasına neden olan 5 temel faktör; kask kullanmamak, emniyet kemeri takmamak, alkollü sürüş, aşırı hız ve çocuk koltuğu kullanmamak olarak öne çıkmaktadır. $\mathrm{Bu} 5$ ana faktörün etkisinin azaltılması için gerekli olan ise bu konudaki kurallara uyulmasını sağlayacak yasaları çıkarmak ve bu yasaların uygulanmasını denetleyebilecek kadrolara sahip olmaktır. 2008-2011 arasında yalnızca 35 ülke bu 5 faktörü hedef alan yasaları çıkartmıştır.

\section{3. Ülkemizdeki Genç Sürücülerin Trafik ve Kaza Analizleri}

Bu makalede, 2000-2017 yılları arasında ülkemizde meydana gelen ölümlü ve yaralanmalı kaza verileri Emniyet Genel Müdürlüğünden alınarak incelenmiştir. Ölümlü kaza, kaza sonucunda sürücü, yolcu ya da yayanın öldüğü kazaları, yaralanmalı kazalar ise sürücü, yolcu ya da yayanın yaralandığı, ölüm olmayan kazaları temsil etmektedir. 2015 yılından önce ki kaza tutanaklarında sadece kaza anındaki durum raporlanırken, bu yıldan sonra sağlık kuruluşuna kaldırılan kazazedenin kazadan 30 gün sonrasına kadar ki durumu takip edilip, 30 gün sonunda kazazedenin mevcut durumu kayıtlara geçirilmeye başlanmıştır. Dolayısı ile bu süreçte hastane de hayatını kaybedenler de istatistiklere dahil edilmiştir.

\subsection{Ehliyet Sahipliği Oranları}

Bu konu başlığı altında, 2000-2017 yılları arasında kazalara karışan kadın ve erkek sürücülerin, sürücü belgeleri incelenmiştir. TÜİK verilerine göre 2017 yılında toplam ülke nüfusu 80.810,252, toplam sürücü sayısı ise 28.181,830 dur. Bu verilere göre toplam nüfusun \% 34'ünün sürücü belgesi sahibi olduğu görülmektedir.

Tablo 1'de 2008-2017 yılları arasındaki nüfus ve sürücü sayıları, toplam nüfus içerisindeki sürücü oranları ayrıca da sürücü sayısı içerisindeki cinsiyet oranları verilmektedir.

Tablo 1. 2008-2017 yılları nüfus ve sürücü sayıları

\begin{tabular}{cccccccc}
\hline Y11 & $\begin{array}{c}\text { Sürücü Sayıs1 } \\
\text { (Milyon) }\end{array}$ & $\begin{array}{c}\text { Nüfus } \\
\text { (Milyon) }\end{array}$ & $\begin{array}{c}\text { Toplam } \\
\text { Sürücü } \\
\text { Oranı (\%) }\end{array}$ & $\begin{array}{c}\text { Erkek } \\
\text { Sürücü } \\
\text { Sayı1 } \\
\text { (Milyon) }\end{array}$ & $\begin{array}{c}\text { Erkek } \\
\text { Sürücü } \\
\text { Oranı (\%) }\end{array}$ & $\begin{array}{c}\text { Kadın Sürücü } \\
\text { Sayı1 } \\
\text { (Milyon) }\end{array}$ & $\begin{array}{c}\text { Kadın } \\
\text { Sürücü } \\
\text { Oranı (\%) }\end{array}$ \\
2008 & $19,337,790$ & $71,517,100$ & 27 & $16,073,831$ & 82,9 & $3,303,959$ & 17,1 \\
2009 & $20,460,739$ & $72,561,312$ & 28 & $16,871,100$ & 82,5 & $3,589,639$ & 17,5 \\
2010 & $21,548,381$ & $73,722,988$ & 29 & $17,457,486$ & 81 & $4,090,895$ & 19 \\
2011 & $22,798,282$ & $74,724,269$ & 30 & $18,270,284$ & 80,1 & $4,527,998$ & 19,9 \\
2012 & $23,760,346$ & $75,627,384$ & 31 & $18,848,281$ & 79,3 & $4,912,065$ & 20,7 \\
2013 & $24,778,712$ & $76,667,864$ & 32 & $19,365,953$ & 78,2 & $5,412,759$ & 21,8 \\
2014 & $25,972,519$ & $77,695,904$ & 33 & $20,055,210$ & 77,2 & $5,917,309$ & 22,8 \\
2015 & $27,489,150$ & $78,741,053$ & 34 & $20,955,650$ & 76,2 & $6,533,500$ & 23,8 \\
2016 & $28,223,393$ & $79,814,871$ & 35 & $21,426,932$ & 75,9 & $6,796,461$ & 24,1 \\
2017 & $28,181,830$ & $80,810,525$ & 34 & $21,097,117$ & 74,9 & $7,084,713$ & 25,1 \\
\hline
\end{tabular}

Tablo verilerine bakıldığında on yıllık dönemde, toplam nüfus içerisindeki genel sürücü oranı \%26, kadın sürücü oranı ise \% 46 artarken, erkek sürücü oranlarında ise \% 10'luk bir azalmanın gerçekleştiği görülmektedir. 
Şekil 1.'de nüfusun ve sürücü sayılarının yıllara göre değişimi gösterilmektedir. Veriler incelendiğinde yıllara göre nüfus ve sürücü sayısında doğru orantılı bir artış gözlemlenmektedir.

Nüfus için;

Sürücü sayısı için;

$$
\mathrm{y}=1027,039 \mathrm{x}-1990728
$$$$
\mathrm{y}=994,181 \mathrm{x}-1976872
$$

$$
\mathrm{R}^{2}=0,999707
$$$$
\mathrm{R}^{2}=0,88834 \text {, }
$$

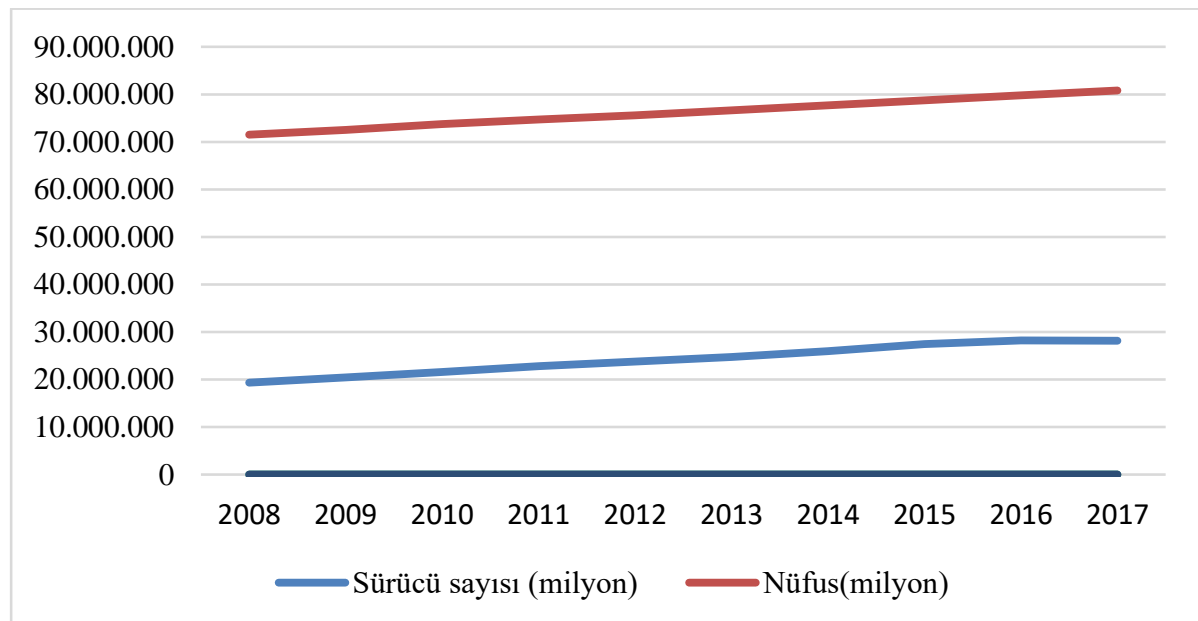

Şekil 1. Sürücü sayısı ve nüfusun yıllara göre değişimi

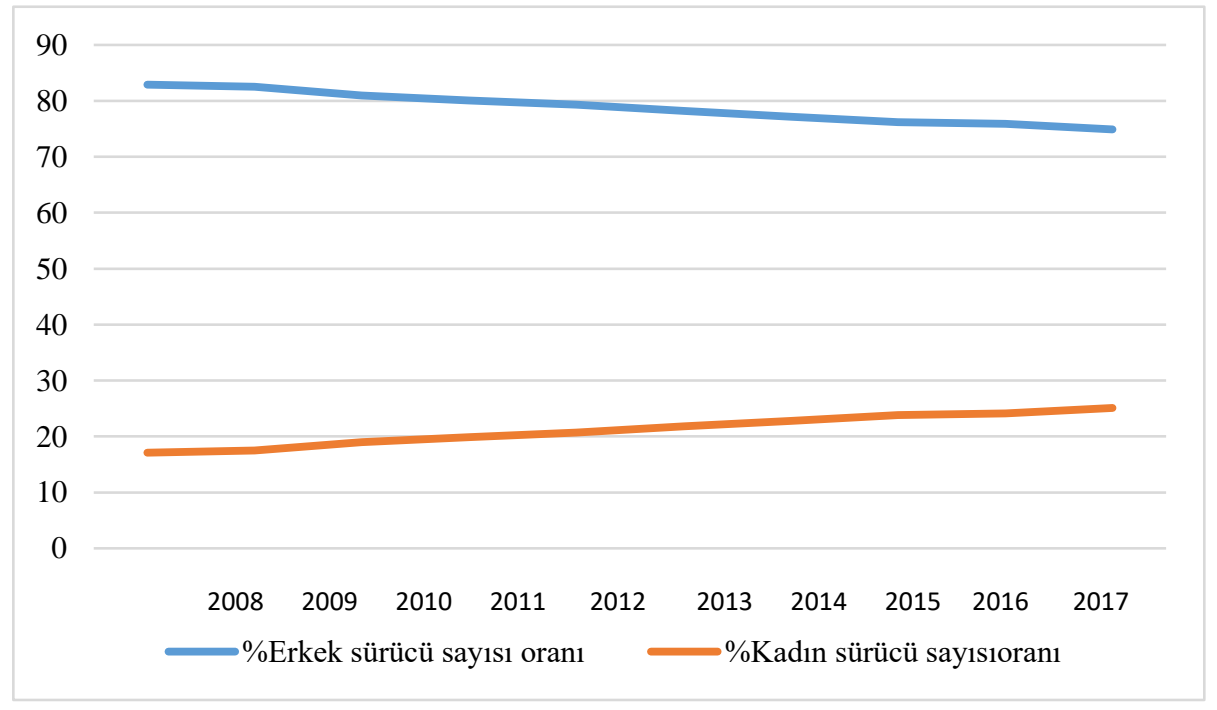

Şekil 2.Kadın ve erkek sürücü oranlarının değişimi

Şekil 2 de, 2008-2017 yılları arasındaki tüm ehliyet sahiplerinin cinsiyete göre oranları ifade edilmiştir.

Bu çalışmada, 2000-2017 yılları arasında kayıtlı sürücü belgesi olan ve kazaya karışan sürücü sayıları, çalışma içeriğinde kullanılan ve Emniyet Genel Müdürlüğü’nden elde edilen kaza verilerine göre analiz edilmiştir. Ehliyet sahibi kişi sayısı ile kazaya karışan ve sürücü belgesi kaza 
tutanaklarında kayda geçmiş sürücü sayıları farklıdır. Kaza verilerinde kullanılan toplam sürücü sayıları ile kadın ve erkek sürücü sayılarının yıllara göre değişimleri ve sürücü sayılarının, kazaya karışan sürücü sayılarına oranları binde olarak Tablo 2.'de verilmiştir.

Tablo 2. Kaza verilerinde kullanılan toplam sürücü sayıları ve kaza oranları

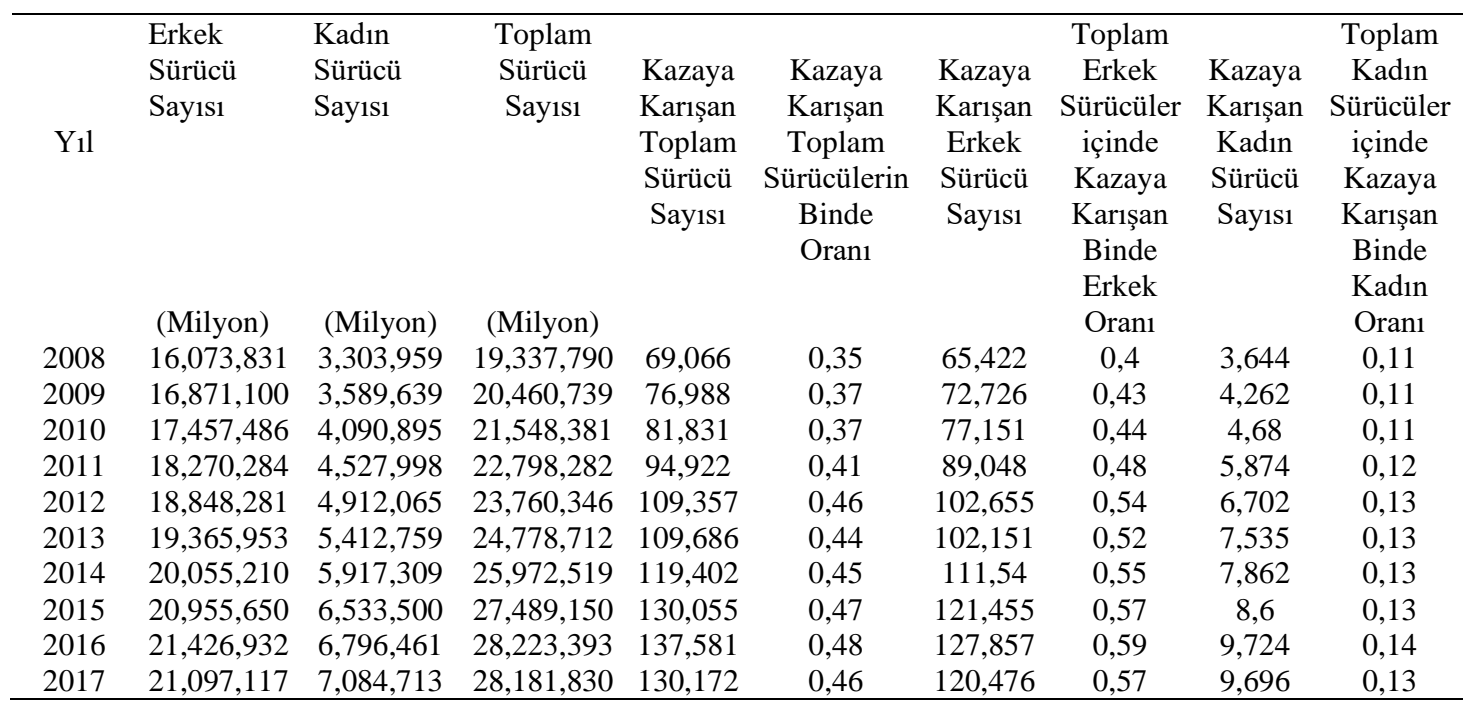

2000-2017 yılları arasında ehliyet sahibi olanların yaş gruplarına göre dağılımları Tablo 3 de sunulmuştur.

Tablo 3. Yaș gruplarına göre sürücü sayıları

\begin{tabular}{llll}
\hline \multicolumn{4}{c}{ Yaş gruplarına göre sürücü belgesi sayısı } \\
Yaş grubu & Erkek & Kadın & Toplam \\
\hline $18-25$ & 263,980 & 15,212 & 279,192 \\
$26-35$ & 461,133 & 36,695 & 497,828 \\
$36-45$ & 349,960 & 24,443 & 374,403 \\
$46-55$ & 219,127 & 8,808 & 227,935 \\
$56-65$ & 92,924 & 2,413 & 95,337 \\
$65+$ & 33,139 & 622 & 33,761 \\
\hline
\end{tabular}

Yukarıdaki tabloya göre, ehliyet sahipliği en fazla olan grup 26-35 yaş grubu olurken, 18-25 yaş arasında toplam 279,192 sürücünün var olduğu görülmektedir.

2000-2017 yılları arasında 18-25 yaş aralığında ehliyet alan toplam 279,192 genç sürücünün, 263,980'i erkek, 15,212'si de kadın sürücüdür. Oransal olarak erkek sürücüler \% 94,5 lik bir oran1 temsil ederken, kadın sürücüler sadece \% 5,5'lik bir oranda kalmaktadırlar.

İnceleme zaman aralığındaki 18-25 yaş aralığının yıllara göre ehliyet sahibi olma değerleri aşağıdaki şekilde gösterilmiştir. 


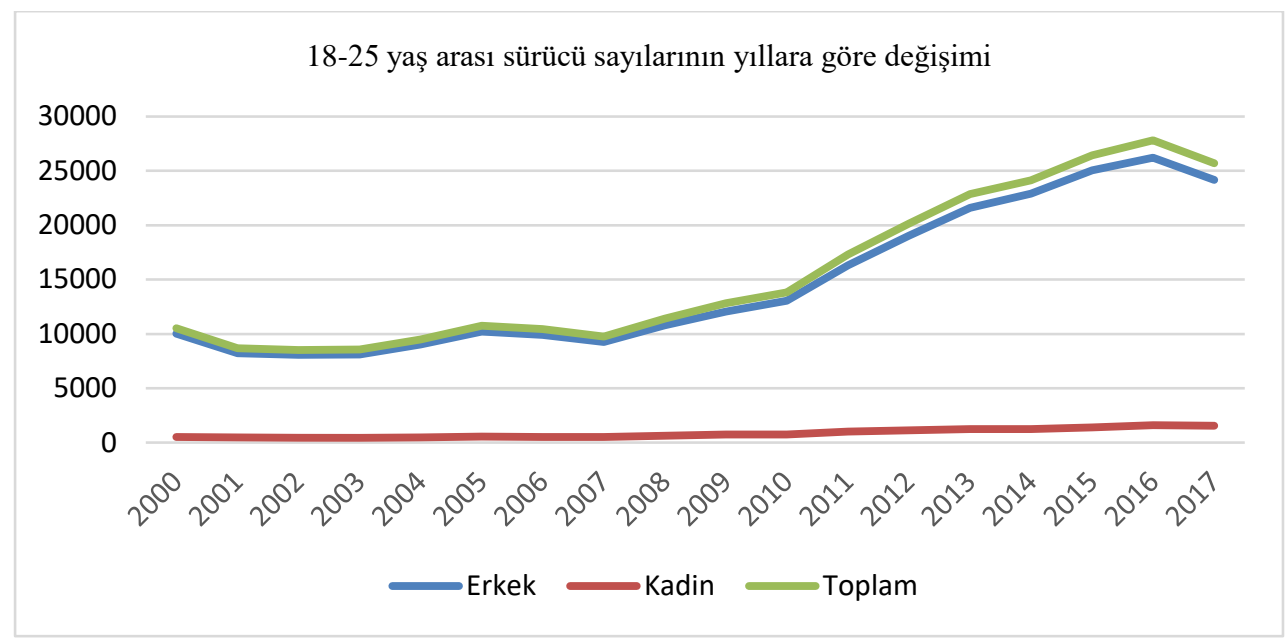

Şekil 3. 18-25 yaş grubu sürücülerin yıllara göre değişimi

\subsection{Kaza Sayları}

2000-2017 yılları arasında gerçekleşen kaza sonucu ölümlü veya yaralanmalı olarak kayıtlara geçen kaza verileri incelenmiş ve bu yıllara ait genel görünüm aşağıdaki tabloda sunulmuştur.

Tablo 4. Toplam ölümlü ve yaralanmalı kaza sayıları

\begin{tabular}{llll}
\hline Kaza sayısı & Erkek & Kadın & Toplam \\
Toplam ölümlü kaza sayısı & 36,701 & 1,077 & 37,778 \\
Toplam yaralanmalı kaza sayısı & $1,538,007$ & 92,820 & $1,630,827$ \\
Toplam kaza sayısı & $1,574,708$ & 93,897 & $1,668,605$ \\
\hline
\end{tabular}

Verilerden de görülebileceği üzere, araştırma dönemine ait ölümlü veya yaralanmalı kazalarda oransal dağılım sırası ile \% 2.26 ve \% 97.74 olarak gerçekleşmiş̧ir. Toplamda gerçekleşen 1.668,605 kazanın 352,250'sine 18-25 yaş grubundaki gençler tarafindan sebep olunmuştur. Bir diğer ifade ile gerçekleşen her 100 ölümlü veya yaralanmalı kazanın 21.1 adeti, inceleme konusu olan genç nüfus tarafindan gerçekleştirilmiştir. Aşağıdaki tabloda ilgili dağılımsal veriler sunulmuştur.

Tablo 5. 2000-2017 yılları 18-25 yaş grubu ölümlü ve yaralanmalı kaza sayıları

\begin{tabular}{llll}
\hline Kaza sayısı & Erkek & Kadın & Toplam \\
Toplam ölümlü kaza sayısı & 5,769 & 204 & 5,973 \\
Toplam yaralanmalı kaza sayıs1 & 328,696 & 17,581 & 346,277 \\
Toplam kaza sayısı & 334,465 & 17785 & 352,250 \\
\hline
\end{tabular}

Toplam kaza sayısı ve kadın sürücülerin yaptığı kaza sayılarına bakıldığında en fazla kaza yapılan yılın 2016 yılı olduğu görülmektedir. Yıllara göre kaza sayılarında genel bir artışın gözlemlendiği verilerde, erkek sürücülerin en fazla yaralanmalı kaza yaptığı yıl ise 2015 yılı olarak öne çıkmaktadır. 


\section{3. Ölüm ve Yaralanma Oranlart}

Ölümlü kazalar incelendiğinde; 18-25 yaş erkek sürücülerin yaptığı ölümlü kazalarda toplam ölen sayıs1 5.860, kadın sürücülerin yaptığı ölümlü kazalarda toplam ölen sayısı ise 232 olarak belirlenmiştir. Bu kazalarda ölen kişi sayısının 1 kişi olduğu kazaların çoğunluğu oluşturduğu, elde edilen sonuçlardan biri olarak ifade edilmelidir. Aşağıda sunulan tablo, bu verilerin yıllara göre dağılımını göstermektedir.

Tablo 6.18-25 yaş grubu sürücülerin yaptığı kazalarda ölen sayıları

\begin{tabular}{|c|c|c|c|c|c|c|c|c|c|c|c|}
\hline \multicolumn{6}{|c|}{$\begin{array}{c}\text { 18-25 yaş grubu erkek sürücülerin yaptığı ölümlü kazalar ve ölen } \\
\text { sayıs1 }\end{array}$} & \multicolumn{6}{|c|}{ 18-25 yaş grubu kadın sürücülerin yaptığı̈ ölümlü kazalar ve ölen } \\
\hline Yil & 1 & 2 & 3 & $3+$ & Toplam & Y1l & 1 & 2 & 3 & $3+$ & Toplam \\
\hline 2000 & 256 & 68 & 33 & 24 & 381 & 2000 & 8 & 6 & & 3 & 17 \\
\hline 2001 & 206 & 82 & 18 & 15 & 321 & 2001 & 9 & 2 & 3 & & 14 \\
\hline 2002 & 190 & 66 & 33 & 24 & 313 & 2002 & 9 & 2 & & & 11 \\
\hline 2003 & 188 & 66 & 24 & 12 & 290 & 2003 & 8 & 2 & & & 10 \\
\hline 2004 & 221 & 56 & 24 & 24 & 325 & 2004 & 5 & 2 & & & 7 \\
\hline 2005 & 221 & 62 & 21 & 24 & 328 & 2005 & 9 & 0 & & & 9 \\
\hline 2006 & 284 & 100 & 51 & 24 & 459 & 2006 & 17 & 2 & & & 19 \\
\hline 2007 & 265 & 102 & 21 & 33 & 421 & 2007 & 12 & 4 & 3 & & 19 \\
\hline 2008 & 239 & 110 & 42 & 48 & 439 & 2008 & 14 & 6 & 6 & & 26 \\
\hline 2009 & 236 & 86 & 51 & 42 & 415 & 2009 & 22 & 6 & & 3 & 31 \\
\hline 2010 & 230 & 72 & 30 & 27 & 359 & 2010 & 14 & 8 & & & 22 \\
\hline 2011 & 174 & 58 & 24 & 12 & 268 & 2011 & 7 & 4 & & & 11 \\
\hline 2012 & 162 & 30 & 18 & 9 & 219 & 2012 & 4 & 2 & & & 6 \\
\hline 2013 & 174 & 62 & 18 & 6 & 260 & 2013 & 8 & 2 & & & 10 \\
\hline 2014 & 170 & 60 & 21 & 15 & 266 & 2014 & 6 & 0 & & & 6 \\
\hline 2015 & 203 & 54 & 12 & 15 & 284 & 2015 & 3 & 0 & & & 3 \\
\hline 2016 & 179 & 60 & 21 & 9 & 269 & 2016 & 4 & 0 & & & 4 \\
\hline 2017 & 160 & 44 & 27 & 12 & 243 & 2017 & 3 & 4 & & & 7 \\
\hline Toplam & 3.758 & 1.238 & 489 & 375 & 5.860 & Toplam & 162 & 52 & 12 & 6 & 232 \\
\hline
\end{tabular}

18-25 yaş grubundaki erkek sürücülerin yaptığı ölümlü kazalarda toplam ölen yaya sayısı 4.245, aynı yaş grubundaki kadın sürücülerin yaptığı ölümlü kazalarda toplam ölen yaya sayısı ise 51 dir. Genç sürücülerin sebep olduğu yaya ölümleri içerikli kazalarda, ölen yaya sayısının 1 olduğu kazalar daha fazla yaşanmaktadır.

2000-2017 yılları arasında gerçekleşen kazalarda toplam 11.985 sürücü hayatını kaybetmiştir. Erkeklerin yaptığ 1 kazalarda toplam 11.504 sürücü hayatını kaybederken, kadınların yaptığ kazalarda ise toplamda 481 sürücü ölmüştür. 18-25 yaş grubu sürücülerinin yaptı̆̆ ölümlü kazalarda toplam ölen sürücü sayısı $1.878^{\prime}$ dir. Bu yaş grubunda, erkek sürücülerin yaptığı ölümlü kazalarda ölen sürücü sayıs1 1.794, kadın sürücülerin yaptığı ölümlü kazalarda toplam ölen sürücü sayısı ise 84 tür. Yıllara göre veri analizi sonucu elde edilen değerler aşağıdaki tabloda belirtilmiştir. 
Tablo 7. Ylllara göre 18-25 yaş grubu sürücülerin yaptığı ölümlü kazalarda ölen sürücü sayıs1

\begin{tabular}{|c|c|c|c|c|c|c|c|}
\hline & \multicolumn{3}{|c|}{ Ölen sürücü sayısı 1} & \multicolumn{3}{|c|}{ Ölen sürücü sayısı 2} & say1s1 \\
\hline Y1l & Erkek & Kadın & Toplam & Erkek & Kadın & Toplam & Genel Toplam \\
\hline 2000 & 109 & 5 & 114 & 2 & & 2 & 116 \\
\hline 2001 & 93 & 1 & 94 & 2 & & 2 & 96 \\
\hline 2002 & 86 & 4 & 90 & & & & 90 \\
\hline 2003 & 86 & 3 & 89 & 8 & & 8 & 97 \\
\hline 2004 & 83 & 1 & 84 & 10 & & 10 & 94 \\
\hline 2005 & 103 & 4 & 107 & 6 & & 6 & 113 \\
\hline 2006 & 131 & 8 & 139 & 6 & & 6 & 145 \\
\hline 2007 & 129 & 8 & 137 & 4 & & 4 & 141 \\
\hline 2008 & 126 & 10 & 136 & 12 & 2 & 14 & 150 \\
\hline 2009 & 126 & 10 & 136 & 10 & & 10 & 146 \\
\hline 2010 & 110 & 11 & 121 & & & & 121 \\
\hline 2011 & 91 & 3 & 94 & 2 & & 2 & 96 \\
\hline 2012 & 70 & 3 & 73 & & & & 73 \\
\hline 2013 & 67 & 4 & 71 & 2 & & 2 & 73 \\
\hline 2014 & 73 & 2 & 75 & 2 & & 2 & 77 \\
\hline 2015 & 82 & 1 & 83 & 2 & & 2 & 85 \\
\hline 2016 & 80 & 3 & 83 & & & & 83 \\
\hline 2017 & 77 & 1 & 78 & 4 & & 4 & 82 \\
\hline Toplam & 1,722 & 82 & 1,804 & 72 & 2 & 74 & 1.878 \\
\hline
\end{tabular}

Sürücü sayılarına ilaveten, genç sürücülerin sebep oldukları kazalarda ölen araç içi yolcu sayıları da analiz edilmiş ve aşağıdaki tablo elde edilmiştir.

Tablo 8. Yıllara göre 18-25 yaş grubu sürücülerin yaptığı kazalarda ölen yolcu sayısı

\begin{tabular}{|c|c|c|c|c|c|c|c|c|c|c|c|}
\hline \multicolumn{6}{|c|}{$\begin{array}{c}\text { 18-25 yaş grubu erkek sürücülerin yaptığı ölümlü kazalarda } \\
\text { ölen yolcu sayısı }\end{array}$} & \multicolumn{6}{|c|}{$\begin{array}{c}\text { 18-25 yaş grubu kadın sürücülerin yaptığ } 1 \text { ölümlü kazalarda } \\
\text { ölen yolcu sayısı }\end{array}$} \\
\hline Y1l & 1 & 2 & 3 & $3+$ & Toplam & Yil & 1 & 2 & 3 & $3+$ & Toplam \\
\hline 2000 & 95 & 40 & 15 & 24 & 174 & 2000 & 4 & & & 3 & 7 \\
\hline 2001 & 81 & 44 & 6 & 6 & 137 & 2001 & 4 & & 3 & & 7 \\
\hline 2002 & 76 & 30 & 15 & 15 & 136 & 2002 & 3 & 2 & & & 5 \\
\hline 2003 & 79 & 28 & 15 & 0 & 122 & 2003 & & 2 & & & 2 \\
\hline 2004 & 88 & 32 & 21 & 6 & 147 & 2004 & 4 & 2 & & & 6 \\
\hline 2005 & 88 & 24 & 15 & 9 & 136 & 2005 & 4 & & & & 4 \\
\hline 2006 & 134 & 50 & 9 & 27 & 220 & 2006 & 2 & 2 & & & 4 \\
\hline 2007 & 117 & 42 & 12 & 27 & 198 & 2007 & 6 & 2 & & & 8 \\
\hline 2008 & 117 & 58 & 21 & 45 & 241 & 2008 & 3 & 6 & & & 9 \\
\hline 2009 & 98 & 60 & 30 & 30 & 218 & 2009 & 10 & 2 & & 3 & 15 \\
\hline 2010 & 109 & 36 & 21 & 24 & 190 & 2010 & 7 & 4 & & & 11 \\
\hline 2011 & 70 & 18 & 24 & 0 & 112 & 2011 & 1 & 2 & & & 3 \\
\hline 2012 & 66 & 22 & 3 & 9 & 100 & 2012 & 1 & & & & 1 \\
\hline 2013 & 77 & 36 & 3 & 6 & 122 & 2013 & 2 & 2 & & & 4 \\
\hline 2014 & 87 & 24 & 18 & 3 & 132 & 2014 & 2 & & & & 2 \\
\hline 2015 & 88 & 24 & 6 & 15 & 133 & 2015 & 2 & & & & 2 \\
\hline 2016 & 76 & 28 & 6 & 15 & 125 & 2016 & 1 & & & & 1 \\
\hline 2017 & 64 & 18 & 12 & 9 & 103 & 2017 & 2 & 2 & & & 4 \\
\hline Toplam & 1.610 & 614 & 252 & 270 & 2.746 & Toplam & 58 & 28 & 3 & 6 & 95 \\
\hline
\end{tabular}

18-25 yaş grubundaki sürücülerin yaptığı ölümlü kazalarda ölen toplam yolcu sayısı 2.841 iken, bu yaş grubundaki erkek sürücülerin yaptığı ölümlü kazalarda ölen yolcu sayısı 2.746, kadın 
sürücülerin yaptığı ölümlü kazalarda ölen toplam yolcu sayısı 95'dir. Dolayısı ile yolcu ölüm oranları erkekler için \% 96.7, kadın sürücülerde ise \% 3.3 olarak gerçekleşmiştir. Tüm yaş grupları ile karşılaştırıldığında ise genç erkek sürücüler, $\% 15.6$, bayan sürücüler ise $\% 0.5$ lik bir paya sahip olmaktadırlar.

Araştırma sürecinde, genç sürücülerin sebep oldukları kazalardaki yaralanma analizleri de yapılmıştır. Aşağıdaki tablo, genç sürücülerin cinsiyetleri dikkate alınarak, inceleme dönemine ait yaralanma verilerine göre sorumlu oldukları yaralananların sayılarını yıllara göre ifade etmektedir.

Tablo 9. Yıllara göre 18-25 yaş grubu sürücülerin yaptığı yaralanmalı kazalarda yaralanan sayıları

\begin{tabular}{|c|c|c|c|c|c|c|c|c|c|c|c|}
\hline \multicolumn{6}{|c|}{ Erkek sürücülerin yaptığı kazalarda yaralanan sayısı } & \multicolumn{6}{|c|}{$\begin{array}{l}\text { Kadın sürücülerin yaptığı kazalarda yaralanan } \\
\text { sayısı }\end{array}$} \\
\hline Y1l & 1 & 2 & 3 & $3+$ & Toplam & 1 & 2 & 3 & $3+$ & Toplam & $\begin{array}{l}\text { Genel } \\
\text { Toplam }\end{array}$ \\
\hline 2000 & 1.073 & 2.048 & 1.662 & 2.241 & 7.024 & 171 & 216 & 108 & 93 & 588 & 7.612 \\
\hline 2001 & 1.047 & 1.756 & 1.458 & 1.665 & 5.926 & 184 & 182 & 108 & 72 & 546 & 6.472 \\
\hline 2002 & 1.040 & 1.800 & 1.434 & 1.749 & 6.023 & 168 & 170 & 81 & 99 & 518 & 6.541 \\
\hline 2003 & 1.042 & 1.686 & 1.368 & 1.812 & 5.908 & 161 & 184 & 84 & 93 & 522 & 6.430 \\
\hline 2004 & 1.031 & 1.864 & 1.446 & 2.067 & 6.408 & 167 & 182 & 84 & 114 & 547 & 6.955 \\
\hline 2005 & 1.112 & 2.012 & 1.575 & 2.139 & 6.838 & 181 & 206 & 165 & 126 & 678 & 7.516 \\
\hline 2006 & 1.201 & 2.156 & 1.950 & 2.907 & 8.214 & 198 & 220 & 111 & 165 & 694 & 8.908 \\
\hline 2007 & 1.233 & 2.102 & 2.055 & 2.904 & 8.294 & 172 & 198 & 147 & 159 & 676 & 8.970 \\
\hline 2008 & 1.244 & 2.206 & 2.133 & 2.994 & 8.577 & 183 & 230 & 162 & 183 & 758 & 9.335 \\
\hline 2009 & 1.255 & 2.320 & 2.349 & 3.573 & 9.497 & 226 & 288 & 165 & 189 & 868 & 10.365 \\
\hline 2010 & 1.269 & 2.356 & 2.439 & 3.735 & 9.799 & 234 & 296 & 213 & 264 & 1.007 & 10.806 \\
\hline 2011 & 1.194 & 2.414 & 2.259 & 3.072 & 8.939 & 249 & 354 & 285 & 210 & 1.098 & 10.037 \\
\hline 2012 & 1.230 & 2.592 & 2.367 & 3.171 & 9.360 & 259 & 382 & 264 & 228 & 1.133 & 10.493 \\
\hline 2013 & 1.256 & 2.660 & 2.586 & 3.234 & 9.736 & 292 & 472 & 321 & 255 & 1.340 & 11.076 \\
\hline 2014 & 1.275 & 2.768 & 2.583 & 3.423 & 10.049 & 321 & 456 & 309 & 234 & 1.320 & 11.369 \\
\hline 2015 & 1.297 & 2.960 & 2.760 & 3.309 & 10.326 & 348 & 458 & 321 & 252 & 1.379 & 11.705 \\
\hline 2016 & 1.315 & 2.866 & 2.700 & 3.498 & 10.379 & 361 & 490 & 351 & 309 & 1.511 & 11.890 \\
\hline 2017 & 1.292 & 2.854 & 2.604 & 3.210 & 9.960 & 348 & 448 & 321 & 291 & 1.408 & 11.368 \\
\hline Toplam & 21.406 & 41.420 & 37.728 & 50.703 & 151.257 & 4.223 & 5.432 & 3.600 & 3.336 & 16.591 & 167.848 \\
\hline
\end{tabular}

18-25 yaş grubu sürücülerin yaptığı yaralanmalı kazalarda toplam yaralanan sayısı 167.848 olup bu rakamın 151.257'e karşılık gelen değeri erkek sürücülerden kaynaklı kazalarla ilgilidir. 18-25 yaş kadın sürücülerin yaptığı yaralanmalı kazalarda ise toplam yaralanan sayısı 16.591 'dir. Bu dönemde toplamda 982.142 kişinin yaralandığı dikkate alınırsa genç erkek ve kadın sürücülerin sebep oldukları kazalarda yaralanan insan sayısı sırası ile, toplam yaralanmalarda \% 15.4 ve \%1.7 lik bir paya sahip olmaktadır.

\subsection{Alkol Oranlart}

Sonucu ölümle ve yaralanmayla biten kazalarda, gençlerin alkollü olarak sebep oldukları kazalarda alkol seviyeleri incelenerek, genç yaş grubundaki sürücülerin kaza sayılarındaki alkol seviyelerinin yıllara bağlı değişimi ortaya konulmuştur. Tablo 10 ve 11 de, 0.5 promil ve altı alkol oranları ile, $0.5-0.9,0.9-1.5,1.5-2.0$ ve $2^{+}$promil değerlerinde kanda alkol seviyeleri olan genç sürücülere ait kaza sayıları cinsiyetlere göre belirtilmiştir. 
Tablo 10. 18 -25 yaş grubu sürücülerinin yıllara göre 0.5 promil ve altı ile $0.5-0.9$ aralığındaki alkol miktarıyla yaptıkları ölümlü kaza sayıları

\begin{tabular}{cccccccc}
\hline \multicolumn{2}{c}{$18-25$ yaş grubu } & 0.5 promil ve alt1 & \multicolumn{3}{c}{$18-25$} & yaş grubu $0.5-0.9$ promil aras1 \\
Kaza Yilı & Erkek & Kadın & Toplam & Kaza Yilı & Erkek & Kadın & Toplam \\
\hline 2002 & 2 & & 2 & 2000 & 2 & & 2 \\
2006 & 2 & & 2 & 2001 & 1 & 1 & 2 \\
2007 & 1 & & 1 & 2002 & 2 & & 2 \\
2008 & 9 & & 9 & 2006 & 1 & & 1 \\
2009 & 6 & 1 & 7 & 2007 & 2 & & 2 \\
2010 & 7 & & 7 & 2010 & 2 & & 2 \\
2011 & 6 & & 6 & 2013 & 2 & & 4 \\
2012 & 1 & & 1 & 2014 & 4 & & 4 \\
2013 & 3 & & 3 & 2015 & 3 & 1 & 4 \\
2014 & 9 & & 9 & 2016 & 4 & & 2 \\
2015 & 1 & & 1 & 2017 & 1 & 1 & $\mathbf{2 7}$ \\
2016 & 8 & & 8 & Toplam & 24 & 3 & \\
2017 & 1 & & 1 & & & & \\
Toplam & 56 & 1 & $\mathbf{5 7}$ & & & & \\
\hline
\end{tabular}

Tablo 11 ise $0.9-1.5,1.5-2.0$ ve $2^{+}$seviyelerindeki alkol değerlerine ait ölümlü kaza sayılarını aynı yaş grubundaki sürücüler için cinsiyetlerine bağlı olarak ifade etmektedir.

Tablo 11. 18-25 yaş grubu sürücülerin yıllara göre, $0.9-1.5,1.5-2.0$ ve $2.0^{+}$promil alkol miktarıyla yaptıkları ölümlü kaza sayıları

\begin{tabular}{|c|c|c|c|c|c|c|c|c|c|c|}
\hline \multicolumn{4}{|c|}{$18-25$ yaş grubu $0.9-1.5$ promil } & \multicolumn{3}{|c|}{$18-25$ yaş grubu $1.5-2.0$ promil } & \multicolumn{4}{|c|}{$18-25$ yaş grubu 2.0 promil ve üstü } \\
\hline Kaza Y1lı & Erkek & Kadın & Toplam & Kaza Yilı & Erkek & Toplam & Kaza Y1li & Erkek & Kadin & Toplam \\
\hline 2000 & 1 & & 1 & 2001 & 2 & 2 & 2001 & 2 & & 2 \\
\hline 2001 & 1 & 1 & 2 & 2003 & 1 & 1 & 2002 & 1 & & 1 \\
\hline 2006 & 1 & & 1 & 2006 & 1 & 1 & 2007 & 1 & & 1 \\
\hline 2007 & & 1 & 1 & 2007 & 4 & 4 & 2008 & 1 & & 1 \\
\hline 2008 & 1 & & 1 & 2009 & 1 & 1 & 2009 & 1 & & 1 \\
\hline 2009 & 2 & & 2 & 2010 & 2 & 2 & 2012 & 1 & & 1 \\
\hline 2010 & 1 & & 1 & 2011 & 2 & 2 & 2013 & 3 & 1 & 4 \\
\hline 2012 & 1 & & 1 & 2012 & 1 & 1 & 2014 & 2 & & 2 \\
\hline 2013 & 4 & & 4 & 2013 & 4 & 4 & 2015 & 5 & & 5 \\
\hline 2014 & 1 & & 1 & 2014 & 1 & 1 & 2017 & 3 & & 3 \\
\hline 2015 & 8 & & 8 & 2015 & 9 & 9 & Toplam & 20 & 1 & 21 \\
\hline 2016 & 8 & & 8 & 2016 & 5 & 5 & & & & \\
\hline 2017 & 1 & & 1 & 2017 & 5 & 5 & & & & \\
\hline Toplam & 30 & 2 & 32 & Toplam & 38 & 38 & & & & \\
\hline
\end{tabular}

Alkol seviyelerine göre genç erkeklerin karıştığı kaza sayıları incelendiğinde; 0.5 promil ve altındaki alkol seviyesinde 56, 0.5-0.9 promil arasi alkol seviyesinde 24, 0.9-1.5 promil alkol seviyesinde 30, 1.5-2.0 promil arası seviyede 38, 2.0 promil ve üstü alkol seviyesinde de 20 ölümlü kazanın meydana geldiği görülmektedir. 2000-2017 yılları arasında 18-25 yaş arası alkollü genç erkek sürücülerin sebep oldukları ve sonucu ölümlü olan kazalarda en çok karşılaşılan alkol miktarının 0.5 promil ve altı olduğu tespit edilmiştir. 
Alkol seviyelerine göre genç kadınların karıştığı kaza sayıları incelendiğinde; 0.5 promil ve altı alkol seviyesiyle 1 ölümlü kaza, 0.5-0.9 promil arası alkol seviyesiyle 3 ölümlü kaza, 0.9-1.5 promil alkol seviyesiyle 2 ölümlü kaza, 1.5-2.0 promil arası alkol seviyesiyle 0 ölümlü kaza, 2.0 promil ve üstü alkol seviyesiyle 1 ölümlü kazanın meydana geldiği belirlenmiştir.

Analiz dönemi olan 2000-2017 yıllarına ait verilere bakıldı̆̆ında, promil bilgisi kayıtlara geçen kazalarda erkeklerde toplam 168, kadınlarda ise 7 ölümlü kaza olduğu görülmüştür. Alkollü ve ölümle sonuçlanan kazaların \% 96' s1 erkekler tarafından gerçekleştirilirken, \% 4'ü kadınlar tarafından gerçekleştirilmiştir..

Benzer analizler aynı yaş grubu ve yıllar dikkate alınarak yaralanmalı kazalar için de yapılmış olup, elde edilen sonuçlar Tablo 12,13 ve 14 de sunulmuştur.

. Tablo 12. 18-25 yaş grubundaki sürücülerin yıllara göre 0.5 promil ve altı ile $0.5-0.9$ arası promil alkol miktarıyla

\begin{tabular}{|c|c|c|c|c|c|c|c|}
\hline \multicolumn{4}{|c|}{$18-25$ yaş grubu 0.5 promil ve altı } & \multicolumn{4}{|c|}{$18-25$ yaş grubu $0.5-0.9$ promil arası } \\
\hline Kaza Yilı & Erkek & Kadın & Toplam & Kaza Y11 & Erkek & Kadin & Toplam \\
\hline 2000 & 55 & 3 & 58 & 2000 & 56 & 1 & 57 \\
\hline 2001 & 44 & & 44 & 2001 & 52 & 1 & 53 \\
\hline 2002 & 48 & 3 & 51 & 2002 & 47 & 3 & 50 \\
\hline 2003 & 28 & & 28 & 2003 & 9 & & 9 \\
\hline 2004 & 15 & & 15 & 2004 & 5 & & 5 \\
\hline 2005 & 8 & & 8 & 2005 & 9 & & 9 \\
\hline 2006 & 48 & & 48 & 2006 & 45 & & 45 \\
\hline 2007 & 48 & & 48 & 2007 & 41 & 1 & 42 \\
\hline 2008 & 243 & 18 & 261 & 2008 & 43 & 5 & 48 \\
\hline 2009 & 211 & 15 & 226 & 2009 & 54 & 2 & 56 \\
\hline 2010 & 235 & 9 & 244 & 2010 & 73 & 1 & 74 \\
\hline 2011 & 268 & 17 & 285 & 2011 & 88 & 5 & 93 \\
\hline 2012 & 236 & 13 & 249 & 2012 & 95 & 2 & 97 \\
\hline 2013 & 477 & 28 & 505 & 2013 & 247 & 14 & 261 \\
\hline 2014 & 578 & 24 & 602 & 2014 & 230 & 16 & 246 \\
\hline 2015 & 585 & 33 & 618 & 2015 & 255 & 19 & 274 \\
\hline 2016 & 680 & 39 & 719 & 2016 & 226 & 7 & 233 \\
\hline 2017 & 603 & 29 & 632 & 2017 & 220 & 11 & 231 \\
\hline Toplam & 4,410 & 231 & 4,641 & Toplam & 1795 & 88 & 1,883 \\
\hline
\end{tabular}

Tablo 13. 18-25 yaş sürücülerinin yıllara göre 0.9-1.5 promil ve 1.5-2.0 promil alkol miktarıla yaptıkları yaralanmalı kaza sayıları

\begin{tabular}{llllllll}
\hline \multicolumn{2}{l}{ 18-25 yaş grubu $0.9-1.5$} & promil arasi & \multicolumn{5}{l}{ 18-25 yaş grubu $1.5-2.0$ promil arasi } \\
Kaza Y1l & Erkek & Kadın & Toplam & Kaza Y1l & Erkek & Kadın & Toplam \\
2000 & 73 & 1 & 74 & 2000 & 39 & & 39 \\
2001 & 89 & 8 & 97 & 2001 & 37 & 1 & 38 \\
2002 & 85 & 2 & 87 & 2002 & 60 & 2 & 62 \\
2003 & 13 & & 13 & 2003 & 10 & & 10 \\
2004 & 17 & 1 & 18 & 2004 & 11 & & 11 \\
2005 & 5 & 1 & 6 & 2005 & 7 & & 7 \\
2006 & 53 & 1 & 54 & 2006 & 43 & 2 & 45 \\
2007 & 60 & 1 & 61 & 2007 & 25 & 1 & 26 \\
2008 & 70 & 1 & 71 & 2008 & 49 & & 49 \\
2009 & 92 & 6 & 98 & 2009 & 49 & 1 & 50 \\
2010 & 121 & 2 & 123 & 2010 & 52 & 1 & 53 \\
2011 & 154 & 12 & 166 & 2011 & 92 & 1 & 93 \\
\hline
\end{tabular}




\begin{tabular}{llllllll}
\hline 2012 & 155 & 6 & 161 & 2012 & 99 & 1 & 100 \\
2013 & 393 & 11 & 404 & 2013 & 218 & 9 & 227 \\
2014 & 435 & 17 & 452 & 2014 & 247 & 12 & 259 \\
2015 & 495 & 31 & 526 & 2015 & 264 & 9 & 273 \\
2016 & 457 & 17 & 474 & 2016 & 282 & 10 & 292 \\
2017 & 429 & 19 & 448 & 2017 & 258 & 2 & 260 \\
Toplam & 3,196 & 137 & $\mathbf{3 , 3 3 3}$ & Toplam & 1,842 & 52 & $\mathbf{1 , 8 9 4}$ \\
\hline
\end{tabular}

Tablo 14. 18-25 yaş grubu sürücülerin yıllara göre 2.0 promil ve üstü alkol miktarıyla yaptıkları yaralanmalı kaza sayıları

\begin{tabular}{llll}
\hline & \multicolumn{2}{c}{$18-25$ yaş grubu 2.0 promil ve üstü } & \\
Kaza Y1l & Erkek & Kadın & Toplam \\
2000 & 16 & & 16 \\
2001 & 67 & 2 & 69 \\
2002 & 68 & 3 & 71 \\
2003 & 6 & & 6 \\
2004 & 7 & & 7 \\
2005 & 4 & & 4 \\
2006 & 30 & 1 & 30 \\
2007 & 27 & 2 & 28 \\
2008 & 40 & 2 & 42 \\
2009 & 58 & 3 & 60 \\
2010 & 46 & 5 & 49 \\
2011 & 59 & 6 & 64 \\
2012 & 70 & 7 & 76 \\
2013 & 184 & 14 & 191 \\
2014 & 205 & 8 & 219 \\
2015 & 203 & 5 & 211 \\
2016 & 203 & 10 & 208 \\
2017 & 236 & 68 & 246 \\
Toplam & 1,529 & & $\mathbf{1 , 5 9 7}$ \\
\hline
\end{tabular}

Alkol seviyelerine göre genç erkeklerin karıştığ kaza sayıları incelendiğinde; 0.5 promil ve altı alkol seviyesiyle 4410, 0.5-0.9 promil arası alkol seviyesiyle 1795, 0.9-1.5 promil alkol seviyesiyle $3196,1.5-2.0$ promil arası alkol seviyesiyle 1842, 2.0 promil ve üstü alkol seviyesiyle de 1529 yaralanmalı kazanın meydana geldiği görülmektedir. 2000-2017 yılları arasında gerçekleşen 18-25 yaş arası alkollü genç erkek sürücüler tarafından sebep olunan ve sonucu yaralanmalı olan kazalarda en çok karşılaşılan alkol miktarının 0.5 promil ve altı olduğu tespit edilmiştir.

Alkol seviyelerine göre genç kadınların karıştığı kaza sayıları incelendiğinde; 0.5 promil ve altı alkol seviyesiyle $231,0.5-0.9$ promil arası alkol seviyesiyle $88,0,9-1,5$ promil alkol seviyesiyle 137, 1.5-2.0 promil arası alkol seviyesiyle 52, 2.0 promil ve üstü alkol seviyesiyle de 68 yaralanmalı kazanın meydana geldiği belirlenmiştir.

Değerler; promil bilgisi kayıtlara geçen kazalarda erkeklerde toplam 12772, kadınlarda ise 576 yaralanmalı kaza verisinin olduğunu göstermektedir. Alkollü ve yaralanmayla sonuçlanan kazaların \% 95.6'sı genç erkekler tarafından gerçekleştirilirken, \% 4.4'ü genç kadınlar tarafından gerçekleştirilmiştir. 


\subsection{Veri Madenciliği Uygulaması}

Trafik kaza analizlerini özel ve karmaşık kılan şey, bu tip olayların belirsiz ve tahmin edilemez oluşlarında saklıdır. Dolayısı ile trafik kazalarının analizi, onları etkileyen faktörlerin tespit edilmesini gerektirmektedir.

Trafik kaza verilerinin analizindeki en sahici problem, bu verilerin heterojen bir yapida olmaları ile ilgilidir. Bu heterojen yapı dikkate alınmazsa, veriler arasındaki bazı ilişkiler saklı kalıp, ortaya konulmamış olabilir. Veri madenciliği uygulamalarından olan Kümeleme Analizleri, trafik kazalarının ortak özelliklerine göre sınıflandırılmalarında oldukça faydalı rol oynamaktadırlar.

WEKA, bilgisayar bilimleri konularından olan makine öğrenimi konusunda kullanılan paket programlardan birisidir. Waikato üniversitesi tarafından açık kaynak kodlu olarak java dili üzerinde

geliştirilmiştir. Altı farklı analizin yapıldığı veri madenciliği uygulamasında örnek olması bakımından iki analiz bu makalede ifade edilecektir.

\subsubsection{Analiz 1}

Destek Değeri: 0.35 (4746 örnek)

Güven Değeri <lift>: 1.1

Kural Sayıs1: 13

Analiz 1' de sürücü cinsiyeti, sürücü belgesi, sürücü emniyet kemeri, alkol sonucu, sürücü kusuru ve kaza sonucu parametreleri incelenmiştir. Analiz 1 sonucunda aşağıdaki çıkarımlara ulaşılmıştır.

BelgeVarYok=1 Sürücü_EmniyetKemeri=1 Sürücü_AlkolSonucu=1 Sürücü_kusur=30 $5886==>$ Kazasonucu=3 5415 conf:(0.92) < lift:(1.11)> lev:(0.04) [532] conv:(2.13)

Sürücü belgesi olan, emniyet kemeri tak1lı, alkolsüz ve sürücünün kusursuz olduğu kazalarda kazanın sonucunda sürücünün sağlam olma olasılığı \% 92'dir. Bu şartları sağlayan 5,415 kaza incelenmiştir.

SurCinsiyet=1 Sürücü_EmniyetKemeri=1 Sürücü_AlkolSonucu=1 Sürücü_kusur=30 $5629==>$ BelgeVarYok=1 Kazasonucu=3 5062 conf:(0.9) < lift:(1.13)> lev:(0.04) [570] conv:(2)

Sürücüsü erkek olan, emniyet kemeri takılı, alkolsüz ve sürücünün kusursuz olduğu kazalarda kazanın sonucunda sürücünün sağlam ve sürücü belgesinin birlikte olma olasılığı \% 90'dır. Bu şartları sağlayan 5,062 kaza incelenmiştir

\subsubsection{Analiz 2}

Destek Değeri: 0.1 (593 örnek)

Güven Değeri <confidence>: 0.9

Kural Sayıs1: 18 
Analiz 5 ' te sürücü cinsiyeti ve sürücü kusuru parametreleri incelenmiştir. Analiz 5 sonucunda aşağıdaki çıkarımlara ulaşılmıştır.

Sürücü_kusur=6 $1020==>$ SurCinsiyet $=1975 \underline{\text { conf:(0.96) }}$

Kaza arkadan çarpma kusurundan kaynaklanıyorsa sürücünün erkek olma olasılığ $1 \% 96$ 'dır. Bu şartları sağlayan 975 kaza incelenmiştir.

Sürücü_kusur=2 $1065==>$ SurCinsiyet=1 $984 \underline{\text { conf:(0.92) }}$

Kaza araç hızını yol, hava ve trafiğin gerektirdiği şartlara uydurmamak kusurundan kaynaklanıyorsa, sürücünün erkek olma olasılığı \% 92'dir. Bu şartları sağlayan 984 kaza incelenmiştir.

Sürücü_kusur=10 $1324==>$ SurCinsiyet=1 $1217 \underline{\text { conf:(0.92) }}$

Kaza doğrultu değiştirme kuralına uymama kusurundan kaynaklanıyorsa, sürücünün erkek olma olasılığı \% 92'dir. Bu şartları sağlayan 1217 kaza incelenmiştir.

Verilerin çeşitliliği ve kapsam genişliğine bağlı olarak; kaza anında tek başına veya yolculu olma, emniyet kemeri kullanımı, kazaların yapıldığı saat ve günler, kazaların konumları da incelenmiş olmakla beraber, bu analiz kriterlerine ait bulgu ve değerlendirmeler, yapılan veri madenciliği analizleri çerçevesinde gelecekteki makalelerde sunulacaktır.

\section{Sonuç ve Değerlendirmeler}

Tüm sürücüler içerisinde genç sürücülerin sayısı hızla artarken, kazaya karışma ve kazalardan zarar görme oranları da aynı oranda artmaktadır. Emniyet Genel Müdürlüğünden alınarak analiz edilen 2000-2017 yıllarına ait kaza verileri ışı̆̆ında 18-25 yaş aralığındaki genç sürücülerin ülkemizde yaşanan ölümlü ve yaralanmalı kazalara yüksek oranlarda karıştıkları belirlenmiştir. 2017 yılı itibari ile sürücü sayısının \% 74,9'unu erkek, \% 25,1'ini de kadın sürücüler oluşturmaktadır. 2000 yılından 2017 yılına kadar erkek nüfusu \% 25 artarken, kazaya karışan erkek sürücü sayısı \% 131 artmıştır. 2008 yılından 2017 yılına kadar ehliyet sahibi erkek sayısındaki artış \% 31 olarak gerçekleşirken, , kazaya karışan erkek sürücü sayısında ise \% 84 lük bir artış oranı söz konusu olmuştur. Kadın sürücüler için yapılan analizlerde, 2000 yılından 2017 yılına kadar kadın nüfusunun \% 24, kazaya karışan kadın sürücü sayısının ise \% 388 arttığı belirlenmiştir. Benzer şekilde 2008 yılından 2017 yılına kadar ehliyet sahibi kadın sayısı \% 114 artarken, kazaya karışan kadın sürücü sayısı \% 166 artmıştır. En fazla erkek sürücünün olduğu yaş 27 iken, kadınlarda ise bu yaş 30 yaşıdır. 18-25 yaş grubundaki sürücülerin $\%$ 94,5'i erkek ,\% 5,5'i kadın sürücülerden oluşmaktadır.

Genç erkek sürücüler incelenen her durumda aynı yaş grubundaki kadın sürücülere kıyasla daha fazla kazaya karışmaktadırlar. Bu sebeple ülkemizdeki genç erkek sürücülerin, bulundukları trafik ortamı ve kültürüne dönük daha kalıcı ve sahici bir eğitim sürecinden geçirilmeleri gerekmektedir. Sahip oldukları risk potansiyeli hakkında bilinçlendirilmeli ve trafik ihlali durumunda tavizsiz, 
ciddi bir bedel ödemeleri sağlanmalıdır. Hukuki düzenlemeler bahsi geçen bu etkinliğin sağlanmasında son derece önemli bir rol oynayacaktır.

Ülkemizde meydana gelen yaralanmalı kaza sayılarının, dünya genelinde de olduğu gibi, ölümlü kaza sayılarından daha fazla olduğu görülmektedir. Kazaların \% 97.74’ü yaralanmalı kaza, \%2.26'sı ölümlü kazadır. Genç sürücülerin karıştıkları kazalarda yaralanmalı kaza sayılarının oranı tüm sürücülerin oranından daha fazladır. Genç sürücülerin karıştıkları kazaların \% 98.31'i yaralanmalı kaza,\% 1.69’u ölümlü kazadır. Ölümlü kaza sayısının kadın ve erkek sürücülerde en fazla olduğu yaş 29' dur. Tüm sürücülerde ölümlü kazaların \% 97.2'si erkek sürücüler, \% 2.8'i kadın sürücüler tarafından yapılmıştır. Gerçekleşen ölümlü kazaların \% 15.8’i ise 18-25 yaş arası olan genç nüfus tarafından yapılmıştır. Genç sürücülerde kadınların ölümlü kaza yapma oranları kendi yaş gruplarında daha fazladır. Ölümlü kazaların \% 96.5'i erkek sürücüler, \% 3.5'i kadın sürücüler tarafından gerçekleştirilmiştir. Yıllara göre bakıldığında tüm sürücülerin toplam ölümlü kaza sayılarında, 2000 yılından 2015 yılına kadar erkek sürücülerin ölümlü kaza sayılarında genel bir azalma görülürken, 2015 yılında tekrar artış gözlemlenmiştir. En fazla kaza yapılan yıllar, erkeklerde 2006, kadınlarda ise 2009 yılıdır. Yaralanmalı kazaların \% 21.2'si genç sürücüler tarafından yapılmıştır. En çok yaralanmalı kaza yapılan yaş erkek sürücülerde 26, kadın sürücülerde ise 30 yaşıdır. Yıllara göre kaza sayılarında görülen artış mevcut uygulamaların etkinliğinin artırılmasının önemini göstermektedir.

Erkek sürücülerin yaptığı ölümlü kazalarda ölen sayılarının \% 16'sı genç erkek sürücülerin karıştığı kazalardan kaynaklanmaktadır. Kadınların yaptığı kazalarda ise genç kadın sürücülerden kaynaklanan ölen sayısı toplam ölen sayısının \% 18.7'si dir. Genç kadın sürücülerin karıştığ ölümlü kazalarda ölen sayıları genç erkek sürücülerin oranlarından daha yüksektir. Bu yaş grubu sürücülerin ölenlerin \% 16 - \% 18'inden sorumlu olmaları, durumun ciddiyetini göstermektedir. Ölen yaya sayılarına bakıldığında yaklaşık aynı oranlar görülmektedir. Erkek sürücülerin yaptığ1 ölümlü kazalarda ölen yayaların \% 16.9' u genç erkek, kadın sürücülerin yaptığı ölümlü kazalarda ölen yayaların \% 18.4’ü genç kadın sürücülerden kaynaklanmaktadır. Yolcu sayılarında ise durum şu şekildedir; Erkek sürücülerin yaptığı ölümlü kazalarda ölen yolcuların \% 15.3 'ü genç erkek sürücülerden, kadın sürücülerin yaptığı ölümlü kazalarda ölen yolcuların \% 18.6'sı genç kadın sürücülerden kaynaklanmaktadır. Genç kadın sürücüler ölen yolcu ve yaya sayılarında hemcinsleri arasında genç erkek sürücülere kıyasla daha yüksek orana sahiptirler. 18-25 yaş arası ölen yaya sayısı, toplam ölen yaya sayıları içerisinde erkekler için \% 10.4, kadınlar için \% 28.2'dir.

Erkeklerin yaptığı kazalarda ölen sürücü sayılarının \% 15.7 'si genç erkek sürücülerden kaynaklanmaktadır. Kadınlarda ise aynı durum farklı yaşlardaki hemcinsleri arasında \% 17.5'dir. Bununla beraber, ölen kişi sayılarında yıllara göre genel dağılımda azalış söz konusudur. Ölen yolcu sayılarının, ölen yaya ve sürücü sayılarından daha fazla olduğu görülmektedir. Ölen sürücü sayıları ise ölen yaya sayılarından daha fazladır. Bu durum tüm genel sürücülerde olduğu gibi genç sürücülerde de benzer yapıdadır. Genç sürücüler sadece kendileri için değil, beraberlerindeki yolcular için de risk taşımaktadırlar. Yaralanan sayılarındaki yapı, ölen sayılarındaki duruma paralellik göstermektedir. Erkek sürücülerin yaptığı yaralanmalı kazalarda yaralanan sayılarının \%16.9'u genç erkek sürücülerin karıştığı kazalardan kaynaklanmaktadır. Kadınların yaptığı kazalarda ise genç kadın sürücülerden kaynaklanan yaralanan sayısı toplam yaralanan sayısının 
\%18.3'ü dür. Yaralanan sayılarını azaltmak, sürücülerin daha az dikkatli olduğu küçük hataların tespit edilmesine ve giderilmesine bağlıdır.

Genç sürücülerin, sürüş yeteneklerine fazla güvenme ve arkadaşlarının etkisine maruz kalma olasılıkları daha yüksektir. Solo sürüşlerde kontrol mekanizmalarının artırılması ve denetim sırasında bu tip sürücülerin daha detaylı incelenmesi, sürücüler açısından yolculuklarında önemsenen ve denetlenen konumuna ait algıyı ve iç denetimi artıracaktır. $\mathrm{Bu}$ da daha güvenli sürücü ve sürüş ortamının oluşmasına olumlu bir katkı yapacaktır. Ülkemizde bu durumla ilgili olarak ehliyet alımını takiben iki yıllık süreçte refakatli sürüş şartının getirilmesi göreceli olarak katı fakat etkin bir yaklaşım olarak benimsenebilir. Özellikle akranlarla yapılan gece yolculuklarında bu düzenleme çok daha etkili bir sonuç üretecektir.

Tüm sürücülerde ölümlü ve yaralanmalı kazalarda en çok karşılaşılan alkol miktarının 0.5 promil ve altı olduğu tespit edilmiştir. Genç otomobil sürücülerini içeren kazalarda da, bu genel eğilime benzerlikler tespit edilmiştir. 2000-2017 yılları arasında 18-25 yaş arası genç erkek sürücüler tarafından sebep olunan alkollü ve sonucu yaralanmalı olan kazalarda da en çok karşılaşılan alkol miktarı 0.5 promil ve altıdır. Görüldüğü gibi çok yüksek alkol oranlarına ulaşılmadan, alkollü sürüşe bağlı kaza oranları bu içerikte en yüksek değerlere sahip olmaktadır. Göreceli düşük miktarlardaki alkole bağlı yüksek miktarlardaki kazaların varlığı, bu anlamdaki denetimlerin ve sıfır tolerans uygulamalarının etkin sonuçlar üretebileceğine vurgu yapmaktadır.

Analiz sonuçlarında, incelenen başlıkların tümünde en yüksek kaza oranına sahip olunan yaş, 2430 yaş aralığı olarak tespit olmuştur. Bu sebeple tezin başlangıcında dünya literatürüne uyumlu olması açısından genç sürücü yaş aralığ olarak seçilen 18-25 yaş aralığı yerine, ülkemizde ehliyet sahipliğinin daha geç yaşlarda başladığı düşünülerek 18-30 yaş aralığının baz alındığı yeni bir çalışmanın daha yapılması önerilmektedir.

\section{Referanslar}

[1] thecityfixturkiye.com

[2] 2.Ulaşım ve Trafik kongresi

[3] Sümer, N.,(2002), Trafik Kazalarında Sosyal Psikolojik Etmenler: Sürücü Davranışları, Becerileri ve Politik Çevre, Türk Psikoloji Yazıları, 5 (9-10), s. 1-36

[4] Amado, S., (2002), Algı Süreçleri: Sürücülük ve Yol Tasarımı İlişkisi, Türk Psikoloji Yazilar1, 5 (9-10), s. 65-81.

[5] Şenel, B., (2013) Türkiye'de Gerçekleşen Trafik Kazaları Üzerine Hata Ağacı Analizi Uygulamas1, Anadolu Üniversitesi Sosyal Bilimler Dergisi, 13(3), s. 65-83

[6] Yüksel, İ., Kurt, M., (2002), Sürücü Stresi Boyutlarının Belirlenmesi, Marmara Üniversitesi Sosyal Bilimler Enstitüsü Dergisi, Cilt: 5, Say1: 18, s. 41-48 
[7] Özkan, T., Lajunen, T., (2005), Multidimensional Traffic Locus of Control Scale (T-LOC): factor structure and relationship to risky driving. Personality and Individual Differences, $38(3)$, s. 533-545

[8] Dünya Sağlık Örgütü, (18 Mart 2013), 2013 Yol Güvenliği Raporu 